\title{
Modeling Gallic Acid Production Rate by Empirical and Statistical Analysis
}

\author{
Bratati Kar $^{1}$, Rintu Banerjee ${ }^{1 *}$ and Bimal Chandra Bhattacharyya ${ }^{2}$ \\ ${ }^{1}$ Microbial Biotechnology \& Downstream Processing Laboratory,Agricultural \& Food Engineering Department, \\ Indian Institute of Technology, Kharagpur - 721 302, India $;{ }^{2}$ Visiting Professor, College of Leather Technology, \\ Calcutta, India
}

\begin{abstract}
For predicting the rate of enzymatic reaction empirical correlation based on the experimental results obtained under various operating conditions have been developed. Models represent both the activation as well as deactivation conditions of enzymatic hydrolysis and the results have been analyzed by analysis of variance (ANOVA). The tannase activity was found maximum at incubation time 5 min, reaction temperature $40^{\circ} \mathrm{C}, \mathrm{pH} 4.0$, initial enzyme concentration $0.12 \mathrm{v} / \mathrm{v}$, initial substrate concentration $0.42 \mathrm{mg} / \mathrm{ml}$, ionic strength $0.2 \mathrm{M}$ and under these optimal conditions, the maximum rate of gallic acid production was $33.49 \mu \mathrm{moles} / \mathrm{ml} / \mathrm{min}$.
\end{abstract}

Key words: Gallic acid, modeling, tannase, Caesalpinia digyna

\section{INTRODUCTION}

Bioconversion of chemical feed stock is an economically viable option to chemical process especially in view of its reduced scale of pollution and energy consumption. Caesalpinia digyna (Teri pod) cover was used as the raw material for the conversion of tannin present in it, to gallic acid under modified solid-state fermentation, with the aid of the enzyme, tannase (tannin acyl hydrolase, EC 3.1.1.20) produced by the microorganism Rhizopus oryzae (RO IIT RB-13 NRRL 21498), locally isolated from the soil of IIT campus. Gallic acid is a phenolic compound (3,4,5-trihydroxy benzoic acid) and is used mainly in pharmaceutical industries for manufacturing trimethoprim (TMP). Trimethoprim is an antibacterial agent, which is usually given along with sulfonamide, and together it has a broad spectrum of action. As microbial processes are less predictable and often more sensitive to environmental variations than chemical reactions (Namdev et al., 1991; Patnaik, 1995) because of the complexity of microbial physiology and their interactions with transport processes, there have been few attempts of theoretical analysis. Mathematical modeling is the

\footnotetext{
Author for correspondence
}

application of mathematics to obtain answers to real world problems. It may be used in a wide range of applications, some of which do not appear initially to be mathematics in nature. Mathematical model together with carefully designed experiments makes it possible to evaluate the behavior of the systems more rapidly than with laboratory experiments only. Models often allow quick and cheap evaluation of alternatives, leading to optimal solutions, which are not otherwise obvious. Moreover, by using models we can better understand or explain natural phenomena and under some conditions we can make predictions in a deterministic or probabilistic sense.

A mathematical model for a microbial process can be expressed using two different mechanisms: structured and unstructured models (Sinclair \& Kristiansen, 1987). The building of kinetic model consists of comparing the predicted values of assumed models with experimental data in order to obtain more relevant correlation. Such model enables the bioengineer to design and control microbial process (Moser and Steiner, 1975) by predicting the behaviour of the same.

Knowledge and an understanding of the kinetics of gallic acid production are of great economical importance in view of the fact that it has got 
immense application in the pharmaceutical industry. Industrial fermenta-tion is gradually moving away from the traditional and largely empirical approach towards simpler and better controlled process (Trilli 1990).

\section{MATERIALS AND METHODS}

Raw Material: Teri pod (Caesalpinia digyna) shrub is found in the forests of the Assam, West Bengal, Andhra Pradesh, Madhya Pradesh and Orissa. The Teri pod cover was readily available from Orissa during the processing of the pod for recovery of oil. It was dried at a temperature of $60^{\circ} \mathrm{C}$ in an oven to remove the moisture. After drying, the pod cover was finely powdered in a grinder and screened to 74-422 $\mu \mathrm{m}$. Oversized particles were recycled. The powder was stored in a cool and dry place at room temperature.

Media: Modified Czapek-Dox medium (Hadi et al., 1994) was used to prepare induced inoculum (Chen, 1969). In the present study, the medium constituted of sodium nitrate $(0.25 \% \quad(w / v))$, potassium dihydrogen orthophosphate $(0.1 \%$ $(\mathrm{w} / \mathrm{v}))$, magnesium sulphate $(0.05 \% \quad(\mathrm{w} / \mathrm{v}))$, potassium chloride $(0.05 \%(\mathrm{w} / \mathrm{v}))$ and Caesalpinia digyna seed cover powder $(2.0 \%(\mathrm{w} / \mathrm{v}))$.

Micro-organism: A fungal strain, Rhizopus oryzae (RO IIT RB-13 NRRL 21498), which was isolated from the soil of Indian Institute of Technology campus, Kharagpur, was used for the production of tannase. The culture was maintained on $2 \%(\mathrm{w} / \mathrm{w})$ malt extract agar slant (Banerjee, 1992).

Fermentation: Biosynthesis experiments were carried out in 250-ml Erlenmeyer flasks containing $100 \mathrm{ml}$ of the modified Czapek-Dox medium without the addition of Caesalpinia digyna pod cover powder, to which $1.0 \mathrm{ml}$ of induced inoculum was added and incubated at $37^{\circ} \mathrm{C}$ for 72 $\mathrm{h}$ in an incubator shaker (Sambros and Instruments India Ltd., India).

Study of tannase kinetics: After fermentation the insoluble material was sedimented by centrifugation in a cold centrifuge (Remi C-24, India). The supernatant was used for study of tannase kinetics under various operating conditions following the assay procedure (Kar et al., 1999).

Modelling: An empirical correlation for predicting the optimum rate of gallic acid production vis-àvis enzymatic reaction influenced by various physicochemical parameters, namely, incubation time (t, min), reaction temperature $\left(\mathrm{T},{ }^{\circ} \mathrm{C}\right), \mathrm{pH}(\mathrm{H})$, initial enzyme concentration (E, v/v), initial substrate concentration $(\mathrm{S}, \mathrm{g} / \mathrm{ml})$, ionic strength of the medium (I, M) has been proposed in the following form:

$\mathbf{P}=\boldsymbol{\emptyset}(\mathbf{t})^{\mathrm{a}}(\mathbf{T})^{\mathrm{b}}(\mathbf{H})^{\mathrm{c}}(\mathbf{E})^{\mathrm{d}}(\mathbf{S})^{\mathrm{e}}(\mathbf{I})^{\mathrm{f}}$

where $\mathrm{P} \quad(\mu \mathrm{moles} / \mathrm{ml} / \mathrm{min})$ is the gallic acid production rate, $\varnothing$ is the dimensional proportionality constant and a, b, c, d, e, f are the exponential coefficients. The exponential coefficients and the proportionality constant were evaluated from the experimental results using Excel spreadsheet (Microsoft Office 97, Microsoft Corp.). All the experiments were conducted in triplicate and the average values were taken. Finally the analysis of the results was carried out by the analysis of variance (ANOVA).

\section{RESULTS}

Results of the enzyme kinetic experiments for the rate of gallic acid production were obtained for the following conditions: incubation time ( $\mathrm{min}), 1,2$, $3,4,5,7,10,15,18,20,25$ and 30 ; reaction temperature $\left({ }^{\circ} \mathrm{C}\right), 8,22.5,30,37,40,45,50,55$ and 60; $\mathrm{pH} \mathrm{3,3.5,} \mathrm{4,} \mathrm{4.5,} \mathrm{5,} \mathrm{5.5,} \mathrm{6;} \mathrm{initial} \mathrm{enzyme}$ concentration $(\mathrm{v} / \mathrm{v}), 0.01,0.02,0.03,0.04,0.08$, $0.12,0.16,0.20$; initial substrate concentration $(\mathrm{mg} / \mathrm{ml}), 0.028,0.035,0.07,0.14,0.21,0.28,0.35$, $0.42,0.49,0.56,0.70,1.4,2.8$; ionic strength (M), $0.025,0.05,0.075,0.1,0.15,0.175,0.2,0.25$. Two trends, activation and deactivation of the rate of enzymatic reaction were observed from the results under the above conditions. Therefore, for each of the above two trends, a correlation between dependent and independent variables was obtained using the Excel spreadsheet. The equations obtained were:

$\mathrm{P}=2.9551 \times 10^{-6}(\mathrm{t})^{0.9614}(\mathrm{~T})^{1.7138}(\mathrm{H})^{4.3848}$ 


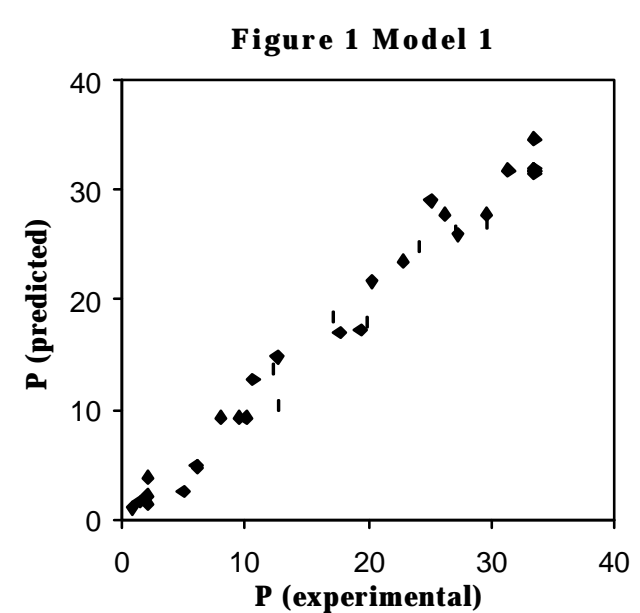

Statistical analysis of model 1 and model 2 were performed using Excel spreadsheet and the results are shown in Tables 1 and 2 respectively.

Table 1 - ANOVA for Model 1

\begin{tabular}{|c|c|c|c|c|c|c|}
\hline Groups & Count & Sum & Average & $\begin{array}{c}\text { Varianc } \\
e\end{array}$ & & \\
\hline Column 1 & 34 & 606.28 & 17.83 & 126.39 & & \\
\hline $\begin{array}{c}\text { Column } 2 \\
\text { ANOVA }\end{array}$ & 34 & 599.43 & 17.63 & 123.32 & & \\
\hline $\begin{array}{l}\text { Source of } \\
\text { Variation }\end{array}$ & $\begin{array}{l}\text { Sum of } \\
\text { squares }\end{array}$ & $\begin{array}{c}\text { Degre } \\
\text { es of } \\
\text { freedo } \\
m\end{array}$ & $\begin{array}{c}\text { Mean } \\
\text { Square }\end{array}$ & $F$-value & $P$-value & $\begin{array}{c}F \\
\text { critical }\end{array}$ \\
\hline $\begin{array}{c}\text { Between } \\
\text { Groups }\end{array}$ & 0.68 & 1 & 0.68 & 0.005 & 0.94 & 3.98 \\
\hline $\begin{array}{l}\text { Within } \\
\text { Groups }\end{array}$ & 8240.61 & 66 & 124.85 & & & \\
\hline Total & 8241.29 & 67 & & & & \\
\hline
\end{tabular}

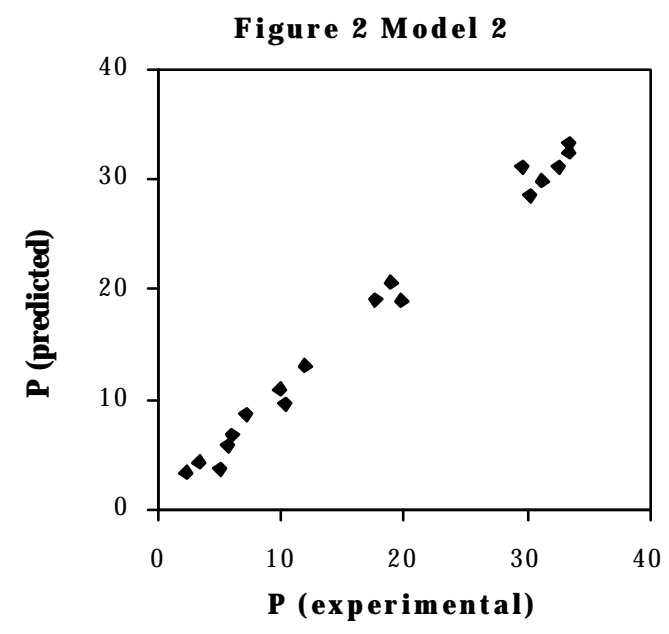

(E) ${ }^{1.6664}(\mathrm{~S})^{0.7094}(\mathrm{I})^{1.1922}$

...(for activation) (2)
$\mathrm{P}=1.9832 \times 10^{8}(\mathrm{t})^{-1.3451}(\mathrm{~T})^{-2.7373}(\mathrm{P})^{-4.8017}$

...(for deactivation) (3)

Model 1 (Figure 1) and model 2 (Figure 2) were developed using equations $2 \& 3$ respectively, which depict the results of $\mathrm{P}$ (predicted) versus $\mathrm{P}$ (experimental).

Table 2 - ANOVA for model 2

\begin{tabular}{|c|c|c|c|c|c|c|}
\hline Groups & Count & Sum & Average & Variance & & \\
\hline Column 1 & 18 & 308.92 & 17.16 & 137.76 & & \\
\hline Column 2 & 18 & 311.03 & 17.27 & 125.65 & & \\
\hline \multicolumn{7}{|l|}{ ANOVA } \\
\hline $\begin{array}{l}\text { Source of } \\
\text { Variation }\end{array}$ & $\begin{array}{l}\text { Sum of } \\
\text { Squares }\end{array}$ & $\begin{array}{l}\text { Degrees } \\
\text { of } \\
\text { freedom }\end{array}$ & $\begin{array}{c}\text { Mean } \\
\text { Square }\end{array}$ & $F$-value & $\begin{array}{c}P- \\
\text { value }\end{array}$ & $\begin{array}{c}F- \\
\text { critical }\end{array}$ \\
\hline $\begin{array}{c}\text { Between } \\
\text { Groups }\end{array}$ & 0.12 & 1 & 0.12 & 0.0009 & 0.97 & 4.13 \\
\hline Within & 4478.24 & 34 & 131.71 & & & \\
\hline Total & 4478.37 & 35 & & & & \\
\hline
\end{tabular}

From tables 1 and 2 it can be seen that F-critical values are greater than the F-values, which indicate that model 1 and model 2 show good agreement with the experimental data. The coefficient of determination $\left(\mathrm{R}^{2}\right)$ and the coefficient of correlation $(\mathrm{R})$ for the rate of gallic acid production in case of model 1 and model 2 were calculated by regression analysis of the experimental data using Excel spreadsheet. The values were as follows: $R^{2}=0.979$ (model 1) and 0.991 (model 2); $\mathrm{R}=0.989$ (model 1) and 0.995 (model 2).

\section{DISCUSSION}

For the development of the model, the system was divided into two parts: model 1 representing the activation trend (rate of gallic acid production from minimum to maximum level) and model 2 representing the deactivation trend (rate of gallic acid production from maximum to minimum level). The model of deactivation trend is the control model for activation trend as the latter system represents only increasing trend.

Further, the models are valid only for the following ranges of the parameters studied: 


\begin{tabular}{lcc}
\hline \multicolumn{1}{c}{ Parameters } & Model 1 & Model 2 \\
\hline $\begin{array}{l}\text { Incubation time (min) } \\
\text { Reaction temperature } \\
\left({ }^{\circ} \mathrm{C}\right)\end{array}$ & $8-40$ & $5-30$ \\
$\mathrm{pH}$ of the medium & $3-4$ & $4-60$ \\
$\begin{array}{l}\text { Initial enzyme } \\
\text { concentration }(\mathrm{v} / \mathrm{v})\end{array}$ & $0.01-0.20$ & \\
$\begin{array}{l}\text { Initial substrate } \\
\text { concentration }(\mathrm{mg} / \mathrm{ml})\end{array}$ & $0.028-2.8$ & \\
$\begin{array}{l}\text { Ionic strength of the } \\
\text { medium }(\mathrm{M})\end{array}$ & $0.025-0.25$ & \\
\hline
\end{tabular}

The objective of the present investigation was to find a suitable correlation for selecting the best combination of microbiological parameters in order to obtain maximum rate of gallic acid production by the enzyme, tannin acyl hydrolase. The coefficient of determination $\left(\mathrm{R}^{2}\right)$ is 0.979 and 0.991 for model 1 and model 2 respectively. The value of $R^{2}$ is the measure of the total variation of the observed value of gallic acid production about the mean explained by the fitted model, which is often expressed in percentage (Rosander, 1951). This implies that $97.9 \%$ and $99.1 \%$ of the total variation in the gallic acid production which have been explained by the fitted models can be attributed to the independent variables, viz., $t, T$, $\mathrm{H}, \mathrm{E}, \mathrm{S}$ and I.

The values of $\mathrm{R}^{2}$ obtained, indicated a good agreement between the experimental and the predicted values of rate of gallic acid production (model 1 and model 2). The regression coefficients are valid for any of the variables studied, placed in the analyzed ranges of the corresponding variables. The coefficient of correlation (R) is 0.989 and 0.995 for model 1 and model 2 respectively. It explains the correlation between the experimental and predicted values from model 1 and model 2 respectively and was considered satisfactory.

The F-values corresponding to tannin acyl hydrolase was 0.005 and 0.0009 for model 1 and model 2 respectively (Tables 1 and 2). The F-value is the ratio of the mean square due to regression to the mean square due to error (Rosander, 1951). In general, the critical F-value should be several times greater than the computed F-values, the null hypothesis is rejected when P-value is greater than the F-value and infers that the variation accounted for by the models was significantly greater than the unexplained variations (Rosander, 1951). In the present study, the null hypothesis was rejected at 0.94 and 0.97 (for model 1 and 2 respectively) for the enzyme, tannase.
The optimal levels of parameters thus obtained from equations (2) \& (3) for maximum tannase hydrolysis were: incubation time, $5 \mathrm{~min}$; reaction temperature, $40^{\circ} \mathrm{C} ; \mathrm{pH}, 4.0$; initial enzyme concentration, $0.12(\mathrm{v} / \mathrm{v}) ; \quad$ initial substrate concentration, $0.42 \mathrm{mg} / \mathrm{ml}$; ionic strength of medium, $0.2 \mathrm{M}$ at which gallic acid production was $33.49(\mu \mathrm{moles} / \mathrm{ml} / \mathrm{min})$.

\section{RESUMO}

Para predizer a taxa das reações enzimaticas uma correlação empírica baseada nos resultados experimentais foi desenvolvida. Os modelos representam a ativação e a desativativação da hydrolise enzimatica. Os resultados foram avaliados pela análise de variança (ANOVA). A atividade máxima da tannase foi obtida após 5 minutos de incubação, temperatura $40^{\circ} \mathrm{C}, \mathrm{pH} 4,0$, concentração inicial da enzima de $0,12 \mathrm{v} / \mathrm{v}$, concentração inicial do substrato $0,42 \mathrm{mg} / \mathrm{ml}$, força iônica 0,2 M. Sob essas condições a taxa máxima de produção ácido galico foi de 33,49 $\mu \mathrm{moles} / \mathrm{ml} / \mathrm{min}$.

\section{REFERENCES}

Banerjee, R. (1992), Some studies on production, purification and characterization of extra-cellular protease by Rhizopus oryzae (RO, IITKGP). Ph.D. thesis, IIT, Kharagpur, India.

Chen, T. (1969), Ph.D. Thesis of Biochemistry. University of California, Berkeley, U.S.A.

Hadi, T. A., Banerjee, R and Bhattacharyya, B. C. (1994), Optimization of tannase synthesis by newly isolated Rhizopus oryzae. Bioproc. Engg., 11, 239243.

Kar, B., Banerjee, R. and Bhattacharyya, B. C. (1999), Microbial production of gallic acid by modified solid sate fermentation. J. Ind. Microbiol. Biotechnol., 23, 173-177.

Moser, A. and Steiner, W. (1975), The influence of the term $\mathrm{k}_{\mathrm{d}}$ for endogenous metabolism on the evaluation of Monod kinetics for biotechnological processes. Eur. J. Appl. Microbiol., 1, 281-289.

Namdev, P. K., Yegneswaran, P. K., Thompson, B. G. and Gray, M. R. (1991), Experimental simulation of large scale bioreactor environments using MonteCarlo method. Can. J. Chem. Eng., 69, 513-519.

Patnaik, P. R. (1995), Sensitivity of recombinant fermentation with run-away plasmids: a structural 
analysis of the effect of dilution rate. Chem. Eng. Commun., 131, 125-140.

Rosander, A. C. (1951), Elementary Principles of Statistics, D. Van Nostrand Company, Inc., New York, pp. 514-539.

Sinclair C. G. and Kristiansen, B. (1987), Fermentation kinetics and modeling. Milton Keynes, Open Univ Press.
Trilli A. (1990), Kinetics of secondary metabolites production. In- Microbial growth dynamics, eds. R. K. Poole, M. J. Bazin and C. W. Keevil, Oxford: IRL Press, Oxford Univ Press, pp. 102-126.

Received March 18, 2000; Revised: April 23, 2000; Accepted September 09, 2000. 